\title{
Az alsó bölcsességfogak mütéti eltávolítását követő késői posztoperatív gyulladás (delayed-onset infection) vizsgálata
}

\author{
Kaposvári István dr. - Körmöczi Kinga dr. - Horváth Ferenc dr. \\ Buglyó Alida - Turai Adrienn Réka - Joób-Fancsaly Árpád dr.
}

Semmelweis Egyetem, Fogorvos-tudományi Kar, Arc-, Állcsont-, Szájsebészeti és Fogászati Klinika, Budapest

\begin{abstract}
Bevezetés és célkitüzés: Az alsó bölcsességfogak mútéti eltávolítását követő késői komplikációkról ritkán olvashatunk a szakirodalomban. A korábban már gyógyultnak hitt, nem várt gyulladással visszatérő páciensek arcduzzanattal, szájzárral, gyakran gennyképződéssel járó, 7 napon túl jelentkező sebfertőzésének előfordulását, hajlamosító tényezőit vizsgáljuk.

Anyag és módszer: A vizsgálati anyagot a budapesti Arc-, Állcsont-, Szájsebészeti és Fogászati Klinika két szakorvosának a 2013 januárjától 2017 augusztusáig terjedő időszakban, összesen 731 betegén végzett 851 bölcsességfog-eltávolítás alkotja. A 26 évnél fiatalabbak körében 150 fő bevonásával retrospektív, a szövődmény előfordulására vonatkozóan eset-kontroll módszerrel kutatjuk a komplikációra hajlamosító tényezőket.

Eredmények: A szövődmény 10 páciensnél (az összes beteg 1,17\%-ánál) lépett fel. Kialakulásáig átlagosan 30 nap telt el. Eset-kontroll vizsgálatunk szignifikánsan igazolta, hogy teljes nyálkahártya-fedettség, a második moláris és a ramus mandibulae közötti helyhiány (Pell-Gregory-féle III-as osztály), mélyebb impactio (Pell-Gregory szerinti B, C), mesioangularis tengelyállás, valamint nagyobb mértékú csontfedettség esetén gyakrabban fordul elő késői posztoperatív gyulladás $(\mathrm{p}<0,05)$. Hajlamosító tényezónek tûnik a fiatalkor és a női nem.

Következtetések: Ajánljuk a rizikópáciensek hosszabban tartó posztoperatív obszervációját, a fokozott szájhigiénia fenntartását. Hívjuk fel pácienseink figyelmét, hogy varratszedés után is fokozott figyelemmel tisztítsák a mútéti területet, panasz esetén pedig azonnal jelentkezzenek. Javasoljuk és tervezzük a téma további kutatását, annak klinikai jelentősége miatt.

Orv Hetil. 2018; 159(31): 1278-1283.
\end{abstract}

Kulcsszavak: bölcsességfog, sebgyógyulás, gyulladás

\section{Incidence and case-control study of delayed-onset infection after lower third molar surgery}

Introduction and aim: Delayed-onset infection was defined as an infectious swelling and trismus accompained by pain or the presence of suppuration starting after the discharge of the patient, generally a week after surgery. Our aim was to describe incidence and possible risk factors of delayed-onset infection after lower wisdoom tooth removal. Material and methods: Retrospective study of 851 lower third molar surgeries, performed between January 2013 and August 2017 at Semmelweis University Faculty of Dentistry, Department of Oro-Maxillofacial Surgery and Stomatology, has been done. The teeth were removed by 2 surgeons. Under age of 26, a case-control study comprising a total of 150 lower third molar surgeries were done to indentify possible risk factors.

Results: 10 delayed-onset wound infections were recorded after suture removal (1.17\% of the patients). The mean time elapsing from surgery to delayed-onset infection was 30 days. Lower third molars with total soft tissue coverage, a bigger amount of bone coverage, a lack of distal space (Pell-Gregory class III), deeper impaction (Pell-Gregory classes $\mathrm{B}, \mathrm{C})$ or mesioangular tilt are associated with the development of this complication $(\mathrm{p}<0.05)$. Female sex and young age seem to be risk factors, too.

Conclusion: Patients with risk factors should be warned that infection may still occur several weeks after surgery. The clinicians should observe these patients longer and emphasize keeping their wound clean for a prolonged period. 
Keywords: third molar, wound-healing, infection, delayed-onset infection, complication

Kaposvári I, Körmöczi K, Horváth F, Buglyó A, Turai AR, Joób-Fancsaly Á. [Incidence and case-control study of delayed-onset infection after lower third molar surgery]. Orv Hetil. 2018; 159(31): 1278-1283.

(Beérkezett: 2018. február 28.; elfogadva: 2018. március 18.)

Klinikánkon évről évre több, áttörésben visszamaradt fog eltávolítására kerül sor. Ezek legnagyobb részét az alsó bölcsességfogak alkotják. A mútéti fogeltávolítás után természetesek a normális gyógyulást kísérő, pár napig tartó utópanaszok. A beavatkozást követően fájdalommal, arcduzzanattal és szájnyitási korlátozottsággal - a mütét időtartamától, a fog anatómiai helyzetétől és egyéb tényezőktől függően - különböző mértékben találkozunk $[1,2]$. Alsó bölcsességfog eltávolítása után viszonylag nagy valószínúséggel lép fel a mútét területén sebgyógyulási zavar $(0,8-7,8 \%)$. A leggyakrabban alveolitis, illetve gennyképződéssel járó fertőzés (surgical site infection) jelentkezik [2-4]. A mütétet követő, korai időszakban kialakuló panaszokat széles körben vizsgálták már, valamint leírták azok hajlamosító tényezőit. A klinikai vizsgálatok többsége azonban csupán a varratszedésig tartó gyulladásos szövődményeket kutatja, ezután nem követik a pácienst [5].

A már gyógyultnak gondolt páciensek körében a mútéti területen hetek elteltével is jelentkezhetnek panaszok. A késői posztoperatív gyulladás (delayed-onset infection) arcduzzanattal, szájnyitási korlátozottsággal és mérsékelt fájdalommal jelentkezik, továbbá pus képződésével, valamint lázzal járhat. A tünetek rendszerint a mütétet követő 3-4 hét elteltével jelentkeznek [1, 5-8].

Vizsgálatunk céljául a késői posztoperatív gyulladás gyakoriságának és hajlamosító tényezőinek meghatározását tüztük ki.

\section{Módszer}

Kutatásunkban a Semmelweis Egyetem Arc-, Állcsont-, Szájsebészeti és Fogászati Klinikájának összesen 731 betegének 851 alsó bölcsességfog mütéti eltávolítását követő sebgyógyulását vizsgáltuk. A beavatkozásokra 2013 januárja és 2017 augusztusa között került sor. A mütéteket a Klinikán alkalmazott protokoll szerint, azonos gyakorlattal rendelkező sebészek végezték el (K. K., J.-F. Á.). A beavatkozásra minden alkalommal helyi érzéstelenítésben, L alakú lebennyel történő feltárásból, buccalis csonteltávolítással került sor. A lebenyszél felfrissítése után a sebszéleket primer módon, 3.0-s vagy 4.0-s Supramid (B. Braun) fonallal, három egyszerú csomós öltéssel és egy horizontális matracöltéssel egyesítették. Az orvosok fájdalomcsillapítóval (diklofenák $50 \mathrm{mg}$, maximális dózis $3 \times 1$ ) és indokolt esetben posztoperatív antibiotikummal (klindamicin $300 \mathrm{mg} 4 \times 1$ vagy amoxicillin-klavulánsav 1000 mg $2 \times 1$ ) látták el betegeiket.
A varratszedés a mútét utáni hetedik napon történt. A betegek figyelmét felhívták, hogy panasz előfordulásakor Klinikánkon jelentkezzenek.

A késői gyulladás kritériuma, hogy az addig szövődménymentesen gyógyuló pácienseknél a beavatkozást legalább 7 nappal követően lép fel a periostitis. Arcduzzanat, szájzár, mérsékelt fájdalom, esetenként láz jelentkezik. A vizsgálatba bevont összes beteg dokumentációját áttekintve kerestük ennek a szövődménynek az előfordulását. Meghatároztuk gyakoriságát, életkor szerinti eloszlását.

150 beteg bevonásával retrospektív eset-kontroll vizsgálatot végeztünk. Mivel a vizsgált szövődmény - kutatásunkban és a korábbi publikációkban is - általában fiatalok körében fordul elő, a random módon kiválasztott pácienseket a 26 év alatti korosztályból választottuk [1, 5]. Szisztémás betegség nem állt fenn, és nem dohányoztak. Páciensenként csak 1 alsó bölcsességfog került be a kutatásunkba. A kontrollcsoport esetén - amennyiben mindkét alsó bölcsességfogat eltávolították, úgy - a korábban mútött fog sebgyógyulását vizsgáltuk. Esetcsoportunkat 10 páciens alkotta, akiknél a korábban részletezett késői gyulladás jelentkezett. A kontrollcsoportot 140, randomizált módon kiválasztott, 26 éven aluli, szövődménymentesen gyógyuló beteg képezte. A kontrollcsoport tizennégyszer több beteget tartalmazott. Ezáltal a vizsgálat statisztikai értékét kívántuk növelni.

Eset-kontroll vizsgálatunk szempontjai az alábbiak voltak: nem, életkor, a fog tengelyállása (Winter-klasszifikáció; 1. ábra), az impactio mélysége (Pell-Gregoryklasszifikáció; 2. ábra), a fog viszonya a mandibula ramusához (Pell-Gregory-klasszifikáció), a fog nyálkahártyafedettségének mértéke (nem fedi, részlegesen fedi, vagy teljesen fedi), a fog csontfedettségének mértéke (nem fedi, részlegesen fedi, vagy teljesen fedi), továbbá posztoperatív antibiotikum alkalmazása [9-11].

Amennyiben késői posztoperatív gyulladás jelentkezett, a következőket regisztráltuk: a mútét és a panaszok jelentkezése között eltelt idő; a gyógyulás során elegendő volt-e az antibiotikumterápia, esetleg drén alkalmazása; szükséges volt-e a mütéti terület excochleatiója. Az eltávolított fog anatómiai viszonyait az adatbázisban tárolt panorámaröntgen segítségével írtuk le.

A statisztikai vizsgálatok kereszttáblás elemzésekkel történtek (statisztikai teszt: Fisher-egzakt próba, IBM SPSS Statistics 24-es program). Vizsgálatunk tervét az illetékes etikai bizottság jóváhagyta (ügyiratszám: 64281/2018/EKU). 


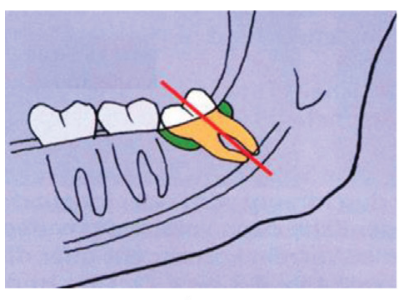

I

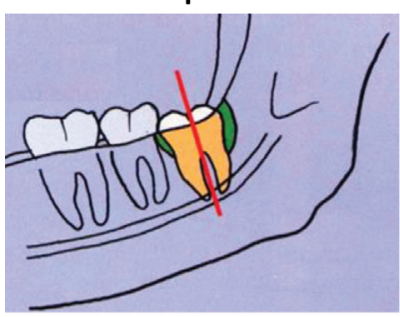

III

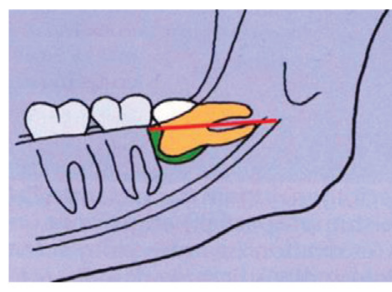

II

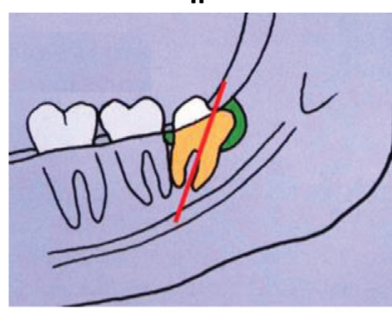

IV

\begin{tabular}{lcl}
\hline Winter-osztály [10] & Eset & Kontroll \\
\hline Horizontális & $20 \%(\mathrm{n}=2)$ & $12,1 \%(\mathrm{n}=17)$ \\
\hline Mesioangularis & $80 \%(\mathrm{n}=8)$ & $44,3 \%(\mathrm{n}=62)$ \\
\hline Vertikális & $0 \%(\mathrm{n}=0)$ & $35,7 \%(\mathrm{n}=50)$ \\
\hline Distoangularis & $0 \%(\mathrm{n}=0)$ & $7,9 \%(\mathrm{n}=11)$ \\
\hline
\end{tabular}

$(\mathrm{p}=0,036$, Fisher-egzakt teszt $)$

1. ábra

Winter-klasszifikáció. I: mesioangularis, II: horizontális, III vertikális, IV: distoangularis $[9,10]$, valamint az eset-kontroll vizsgálat eredményei

\section{Eredmények}

A szövődmény 10 páciensnél (az összes beteg 1,17\%ánál) lépett fel. Kialakulásáig átlagosan 30 nap telt el. Jelentkezése minimum 20, maximum 80 nappal követte a mútétet. A legfiatalabb beteg, akinél a szövődmény kialakult, 15 éves, a legidősebb 22 éves volt (3. ábra). Életkoruk átlagosan 18,6 év (szórás: 2,1) volt. A szövődménnyel járó összes esetben a páciens a mútét után antibiotikumot kapott (per os amoxicillin-klavulánsav 1000 $\mathrm{mg} 2 \times 1$ vagy klindamicin $300 \mathrm{mg} 4 \times 1$ ). A gyulladás kezelésekor nyolc esetben elegendőnek bizonyult az antibiotikumterápia (amoxicillin-klavulánsav $1000 \mathrm{mg} 2 \times$ $\mathrm{l}$ vagy klindamicin $300 \mathrm{mg} 4 \times 1$ ). Purulens duzzanat esetén incisio, jodoformos drenázs történt. Két esetben a panaszok 7 napon túl történő fennállása miatt a korábbi mútéti terület feltárására, excochleatiójára volt szükség.

A 26 éven aluli korosztályon belül végzett eset-kontroll vizsgálat során a kontrollcsoportban a legfiatalabb beteg 15 éves, a legidősebb 25 éves volt. Átlagéletkoruk 21,1 év (szórás: 2,8) volt (3. ábra).

$\mathrm{Az}$ esetcsoportban 80\%, míg a kontrollcsoportban $68,8 \%$ volt a nők aránya. Statisztikailag szignifikáns eltérést nem találtunk a nemekre vonatkozóan. A szövődmény előfordulásakor a bölcsességfog minden esetben $(10 / 10)$ teljesen a nyálkahártya alatt helyezkedett el. A kontrollok 35,7\%-ánál (50/140) teljesen, 55,7\%-ánál
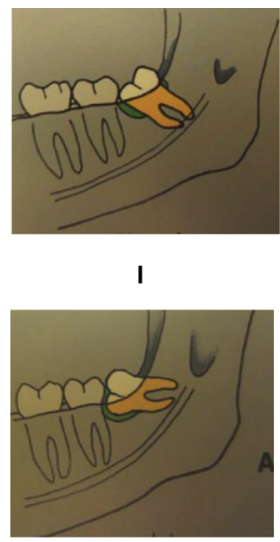

A
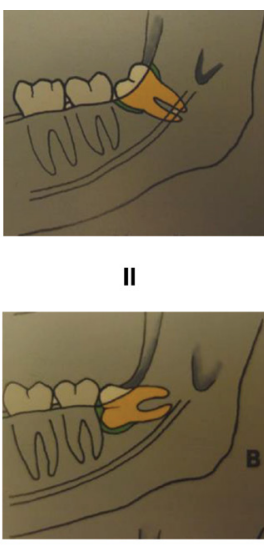

B

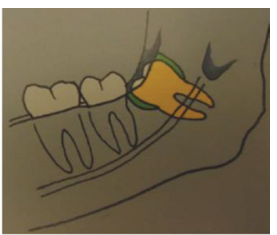

III

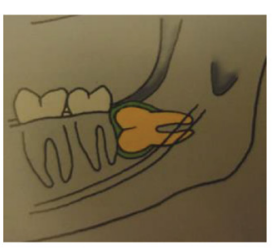

C

\begin{tabular}{llc}
\hline Ramusviszony & Eset & Kontroll \\
\hline I. & $0 \%(\mathrm{n}=0)$ & $55,7 \%(\mathrm{n}=78)$ \\
\hline II. & $20 \%(\mathrm{n}=2)$ & $40,7 \%(\mathrm{n}=57)$ \\
\hline III. & $80 \%(\mathrm{n}=8)$ & $3,6 \%(\mathrm{n}=5)$ \\
\hline$(\mathrm{p}=0,000$, Fisher-egzakt teszt $)$ & & \\
\hline Impactio mélysége & Eset & Kontroll \\
\hline A & $20 \%(\mathrm{n}=2)$ & $64,3 \%(\mathrm{n}=90)$ \\
\hline B & $80 \%(\mathrm{n}=8)$ & $35,0 \%(\mathrm{n}=49)$ \\
\hline $\mathrm{C}$ & $0 \%(\mathrm{n}=0)$ & $0,7 \%(\mathrm{n}=1)$ \\
\hline$(\mathrm{p}=0,017$, Fisher-egzakt teszt $)$ & & \\
\hline
\end{tabular}

2. ábra $\quad$ Pell-Gregory-klasszifikáció. Alapja a trigonum retromolare hosszúsága, a fog okklúziós síkjához viszonyított helyzete, valamint az impactio mértéke [9]. Az eset-kontroll vizsgálat eredménye

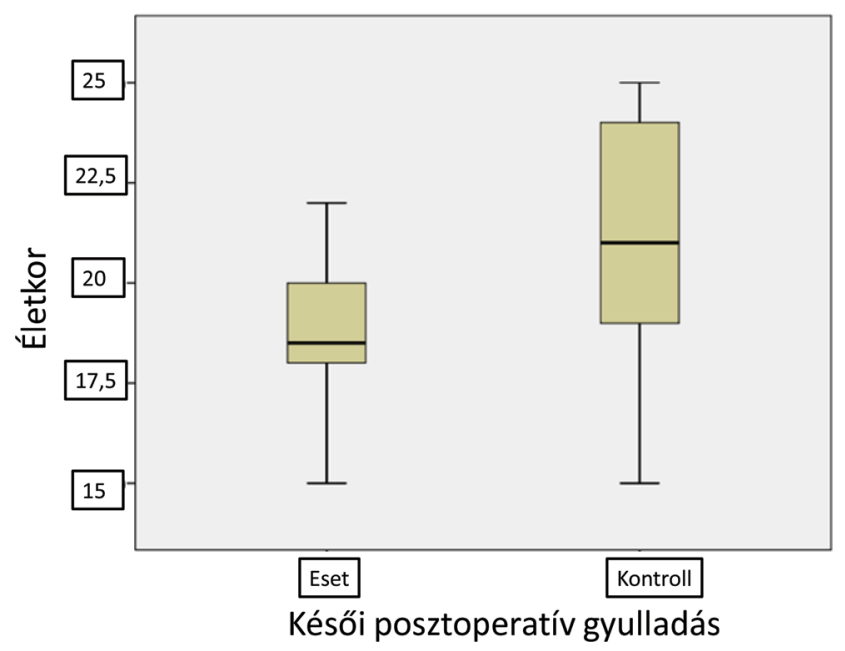

3. ábra $\quad$ Az eset-kontroll vizsgálat koreloszlása

(78/140) részlegesen, 8,6\%-ánál (12/140) pedig egyáltalán nem borította nyálkahártya a bölcsességfogat (4. ábra).

Teljes nyálkahártya-borítottság esetén gyakrabban fordult elő a szövődmény ( $\mathrm{p}=0,000$, Fisher-egzakt teszt). Teljesen $(3 / 10)$, illetve részben $(7 / 10)$ csonttal borított 


\begin{tabular}{lcc}
\hline Nyálkahártya-borítottság & \multicolumn{1}{l}{ Eset } & Kontroll \\
\hline Nem fedi & $0 \%(\mathrm{n}=0)$ & $8,6 \%(\mathrm{n}=12)$ \\
\hline Részben & $0 \%(\mathrm{n}=0)$ & $55,7 \%(\mathrm{n}=78)$ \\
\hline Teljesen & $100 \%(\mathrm{n}=10)$ & $35,7 \%(\mathrm{n}=50)$ \\
\hline$(\mathrm{p}=0,000$, Fisher-egzakt teszt $)$ & & \\
\hline Csontfedettség & Eset & Kontroll \\
\hline Nem fedi & $0 \%(\mathrm{n}=0)$ & $25,0 \%(\mathrm{n}=35)$ \\
\hline Részben & $70 \%(\mathrm{n}=7)$ & $72,1 \%(\mathrm{n}=101)$ \\
\hline Teljesen & $30 \%(\mathrm{n}=3)$ & $2,9 \%(\mathrm{n}=4)$ \\
\hline ( $\mathrm{p}=0,002$, Fisher-egzakt teszt $)$ & & \\
\hline
\end{tabular}

4. ábra | A nyálkahártya-borítottság és a csontfedettség mértéke

bölcsességfogak eltávolításakor fordult elő a komplikáció. A kontrollcsoport 2,9\%-ában (4/140) teljes, 72,1\%ában (101/140) pedig részleges csontfedettséggel találkoztunk, míg 25\%-ában (35/140) teljesen előtört fogat távolítottak el (4. ábra). A fog teljes csontfedettségével a szövődményes esetek között gyakrabban találkoztunk ( $\mathrm{p}$ $=0,002$, Fisher-egzakt teszt). A tengelyállást tekintve a 10 szövődményes eset 20\%-át horizontálisnak, 80\%-át mesioangularisnak találtuk. A kontrollcsoport 12,1\%-át (17/140) horizontális, 44,3\%-át (62/140) mesioangularis, 35,7\%-át $(50 / 140)$ vertikális, $7,9 \%$-át $(11 / 140)$ pedig distoangularis tengelyállású fogak alkották ( 1 . ábra). Mesioangularis tengelyállás esetén gyakrabban fordult elő a szövődmény $(\mathrm{p}=0,036$, Fisher-egzakt teszt).

$\mathrm{Az}$ esetcsoportban 20\%-ban (2/10) II-es, 80\%-ban (8/10) III-as Pell-Gregory-osztályú fogakkal találkoztunk. A kontrollok között 55,7\%-ban (78/140) I-es, $40,7 \%$-ban $(57 / 140)$ II-es, 3,6\%-ban $(5 / 140)$ III-as osztályú fogakat távolítottak el (2. ábra). A Pell-Gregory-féle III-as osztály esetén gyakrabban alakult ki a szövődmény ( $\mathrm{p}=0,000$, Fisher-egzakt teszt).

A szövődménnyel járó esetek $80 \%$-a $(8 / 10)$, míg a véletlenszerüen kiválasztott kontrollpáciensek 35\%-a (49/140) esett a mélyebb impactiót jelentő Pell-Gregory-féle B csoportba. A besorolás szerinti A osztályú fogak az esetcsoport $20 \%$-át $(2 / 10)$, míg a kontrollcsoport 64,3\%-át (90/140) alkották (2. ábra). Az ugyanezen besorolás szerinti, legmélyebb impactiót jelentő C osztályú foggal csak a kontrollcsoportban találkoztunk, mindöszsze egy esetben. A szövődményes esetek között gyakrabban fordult elő a mélyebb impactiót jelentő B osztály $(\mathrm{p}=0,017$, Fisher-egzakt teszt) .

Az esetcsoport mindegyik páciense a mútét után antibiotikumot kapott (klindamicin $300 \mathrm{mg} 4 \times 1$ négy napon keresztül vagy amoxicillin-klavulánsav $1000 \mathrm{mg} 2 \times$ l egy héten keresztül).

A kontrollcsoport 120 páciense kapott a feljebb leírt módon posztoperatív antibiotikumot. A mútét után adott antibiotikum tekintetében az elvégzett kereszttáblás elemzés nem mutatott szignifikáns eltérést az eset- és kontrollcsoport között.

\section{Megbeszélés}

A bölcsességfog-eltávolításon áteső páciensek átlagéletkora egyre csökken, ugyanis gyakrabban kerül sor profilaktikus beavatkozásra. A cél általában a nehezített fogáttörés tüneteinek, valamint a késóbbi fogtorlódásnak a megelózése [2].

Az áttörésében visszamaradt bölcsességfogak sebészetét illető́n napjainkban új irányvonalak is körvonalazódnak. Ezek közül egyre gyakrabban kerül sor a fog csíraállapotában való eltávolítására, valamint a - korábban csak érdekességként említett, mára azonban teljesen elfogadott szájsebészeti eljárássá vált - coronectomiára [1, 12].

A bölcsességfogak fejlődése 20-25 éves korban fejeződik be. A fogak ekkorra érik el végleges pozíciójukat. Fejlődésük korábbi időszakában a mandibula felhágó ágában mélyebben, distalisabban helyezkednek el [9]. Amennyiben ilyenkor távolítják el azokat, az anatómiai elhelyezkedésből kifolyólag a mútétet követő gyógyulás körülményei kedvezőtlenebbek, a seb tisztíthatósága komplikáltabb. Ez azonban érdekes módon nem a mútétet követő korai idôszakban jelent problémát [1, 5-8].

Monaco és mtsai 134 alsó bölcsességfogcsíra eltávolítása után vizsgálták a betegek gyógyulását. A fiatal betegek csupán $0,9 \%$-ánál fordult elő gyulladásos szövődmény a mútétet követő egy héten belül. A vizsgálat során meglepően nagy arányban, 9,2\%-ban találkoztak a varratszedés utáni, a mútétet 3-4 héttel követó gyulladással [1].

A szerzők szerint a korai posztoperatív szövődmények alacsony előfordulása a sebészi technika tökéletesítésének, valamint az adott esetben javallott antibiotikumprofilaxisnak, antiszeptikumok használatának tulajdonítható $[1,13]$. Mindezek azonban több hét elteltével már nem hatásosak a seb fertőzésének megakadályozásában [1]. Felmerül, hogy a perioperatív szisztémás és lokális antibakteriális terápia elősegíti a késői opportunista fertőzések kialakulását [6]. Piecuch és mtsai a bölcsességfog-eltávolítás utáni fertőzéseket vizsgálták. Perioperatív antibiotikum alkalmazásakor 2,58\%-ban, míg annak hiányában ritkábban, 1,2\%-ban találkoztak késő́i infekcióval [14]. Ezek alapján nagy valószínúséggel kijelenthetjük, hogy a perioperatív farmakológiai terápia nem meghatározó a késői fertőzés kialakulása szempontjából. Vizsgálatunkban a posztoperatív antibiotikumot illetôen az eset- és a kontrollcsoportunk között szignifikáns különbséget nem találtunk.

Fontosnak tartjuk megjegyezni, hogy a mútét előtt indított antibiotikum az irodalmi adatok szerint jelentősebb redukciós hatással bír a korai gyulladásos szövődményekre, mint a csak posztoperatíven alkalmazott.

A gyógyszeres terápia szükségességéről azonban sokszor csak a mútét közben vagy az után tudunk döntést hozni [13].

A megbetegedés etiológiáját tekintve az anatómiai tényezők tǘnnek kulcsfontosságúnak $[1,5-8]$. Germectomia esetén a fog teljes egészében csonttal fedetten helyezkedik el. A sebész ilyen esetekben a sebet általában 
per primam zárja. A második moláris fog és a felhágó ág közötti helyhiány miatt azonban a seb nehezen tisztítható. A sebbe kerülő ételmaradék - mint a baktériumok táptalaja - amolyan 'egyirányú ajtón' átjutva kerül a nyálkahártya alá, viszont távozni onnan már nem tud. A korábbi mútéti területen így 'ételimpactio' hatására gyulladás alakulhat ki $[15,16]$.

Figueiredo és mtsai négy alkalommal publikáltak ebben a témában. Megállapították, hogy a szövődmény bár ritkán (1,5\%-ban) fordul elő, mégis fontos a páciensek felvilágosítása arról, hogy a mútét után több héttel is kialakulhatnak nem várt panaszok. 33 késői típusú gyulladás kezelésének a vizsgálata során az antibiotikus terápiát az esetek többségében elegendőnek találták. Amennyiben a páciens panaszai 7 nap elteltével sem csökkennek, szükségessé válik a korábbi műtéti terület sebészi revíziója [5-8].

12 késői típusú gyulladásból vett bakteriológiai minta alapján a szövődmény kezelésére a klindamicint javasolják, amennyiben perioperatívan amoxicillint alkalmaztak. A feltételezett kórokozók (Fusobacterium sp., Prevotella sp., Peptostreptococcus sp.) leginkább erre érzékenyek, miközben az amoxicillin-klavulánsav kevésbé hatékonynak, az önálló amoxicillin pedig a legtöbb esetben hatástalannak bizonyult $[7,8]$. Retrospektív eset-kontroll vizsgálatukban a kutatók arra jutottak, hogy a fog anatómiai helyzete döntő tényezője a szövődmény kialakulásának. A teljes nyálkahártya-fedettséget, a vertikális/ mesioangularis tengelyállást, valamint a bölcsességfog mögötti helyhiányt, a mi vizsgálatunkkal megegyezően, hajlamosító tényezőknek találták $[5,6]$.

Célunk a keveset kutatott, késői posztoperatív gyulladásról az eddigi szakirodalomból megszerzett információk felülvizsgálata, illetve gyarapítása volt. Leszögezhetjük, hogy helyes a megállapítás, amelynek értelmében a szövődmény fiatalokra jellemző. Legidősebb páciensünk, akinél ilyen panaszok jelentkeztek, 22 éves volt. Kutatásunkban a szövődmény 1,17\%-os előfordulása közel áll a Figueiredo és mtsai által megadott 1,5\%-os értékhez, azonban jóval alatta marad a Monaco és mtsai által megfigyelt 9,17\%-os incidenciának. Ennek magyarázata az lehet, hogy az utóbbi szerző vizsgálatában csak fogcsíraeltávolítások szerepeltek, amely esetekben nagyobb a késői gyulladás kockázata.

Kutatásunkban a szövődmény kialakulásáig átlagosan 30 nap telt el, ami megfelel a korábbi publikációkban megadott 25-34 napnak. Vizsgálatunkban a gyulladás kezelésekor $80 \%$-ban az antibiotikumterápia - purulens duzzanat esetén incisio, jodoformos drenázs - elegendőnek bizonyult. 20\%-ban a panaszok 7 napon túl történő fennállása miatt a korábbi mútéti terület feltárására, excochleatiójára volt szükség. Korábbi publikációk hasonló arányban (10-33\%) tartották szükségesnek a gyulladt terület sebészi revízióját $[1,5,8]$.

A 26 éven aluli korosztályban végzett eset-kontroll vizsgálatunkban igazoltuk, hogy a fog elhelyezkedésének meghatározó szerepe van. Az anatómiai viszonyokat te- kintve teljes nyálkahártya-fedettség, nagyobb mértékü csontfedettség, mesioangularis tengelyállás, mélyebb impactio (Pell-Gregory-féle B), a második moláris fog és a mandibula felhágó ága közötti helyhiány (Pell-Gregory szerinti II-es és III-as osztály) esetén szignifikánsan gyakrabban jelentkezett a komplikáció. Tekintettel arra, hogy az összes szövődményes esetünk bonyolultabb mütétnek tekinthető, a pácienseket perioperatív antibiotikumprofilaxisban részesítettük, ezért ennek hatását a késői posztoperatív gyulladásra nem volt lehetőségünk vizsgálni.

\section{Következtetés}

Egy mütét várható szövődményeinek ismerete mind a kezelőorvos, mind pedig a páciens számára fontos. Különösen igaz ez az olyan kórképekre, amelyek kialakulása fokozott odafigyeléssel csökkenthető. Ezek közé sorolható az alsó bölcsességfog eltávolítását követő késői posztoperatív gyulladás. Ajánljuk a rizikópáciensek hoszszabban tartó obszervációját, a fokozott szájhigiénia fenntartását. Hívjuk fel pácienseink figyelmét, hogy varratszedés után is fokozott figyelemmel tisztítsák a mútéti területet, panasz esetén pedig azonnal jelentkezzenek.

Javasoljuk és tervezzük a téma további kutatását, annak klinikai jelentősége miatt.

Anyagi támogatás: A közlemény megírása anyagi támogatásban nem részesült.

Szerzői munkamegosztás: K. I., K. K., H. F., B. A., T. A. R., J.-F. Á. a vizsgálatokat, K. K. és J.-F. Á. a mútéteket végezték. Statisztikai elemzések: H. F. és K. I. A cikk végleges változatát valamennyi szerző elolvasta és jóváhagyta.

Érdekeltségek: A szerzőknek nincsenek érdekeltségeik.

\section{Köszönetnyilvánítás}

Kaposvári István köszöni a családjának és a Semmelweis Egyetem, FOK, Arc-, Állcsont-, Szájsebészeti és Fogászati Klinika összes dolgozójának a segítségét.

\section{Irodalom}

[1] Monaco G, Cecchini S, Gatto MR, et al. Delayed onset infections after lower third molar germectomy could be related to the space distal to the second molar. Int J Oral Maxillofac Surg. 2017; 46: 373-378.

[2] Joób-Fancsaly Á. (ed.) The role of wisdom teeth in dentistry. [A bölcsességfogak szerepe a fogászat különböző szakterületein.] Semmelweis Kiadó, Budapest, 2010. [Hungarian]

[3] Andersson L, Kahnberg KE, Pogrel MA. (eds.) Oral and maxillofacial surgery. Wiley-Blackwell, Hoboken, NJ, 2010.

[4] Divinyi T. The management of partially erupted and unerupted teeth (impacted and retained teeth). In: Szabó Gy. (ed.) Oral and maxillofacial surgery. [Áttörésben visszamaradt fogak sebészi ellátása (impaktált, retineált fogak). In: Szabó Gy. (szerk.) Száj- 
sebészet, maxillofacialis sebészet.] Semmelweis Kiadó, Budapest, 2001; pp. 69-78. [Hungarian]

[5] Figueiredo R, Valmaseda-Castellón E, Berini-Aytés L, et al. Incidence and clinical features of delayed-onset infections after extraction of lower third molars. Oral Surg Oral Med Oral Pathol Oral Radiol Endod. 2005; 99: 265-269.

[6] Figueiredo R, Valmaseda-Castellón E, Berini-Aytés L, et al. Delayed-onset infections after lower third molar extraction: a casecontrol study. J Oral Maxillofac Surg. 2007; 65: 97-102.

[7] Figueiredo R, Valmaseda-Castellón E, Formoso-Senande MF, et al. Delayed-onset infections after impacted lower third molar extraction: involved bacteria and sensitivity profiles to commonly used antibiotics. Oral Surg Oral Med Oral Pathol Oral Radiol. 2012; 114: 43-48.

[8] Figueiredo R, Valmaseda-Castellón E, Laskin DM, et al. Treatment of delayed-onset infections after impacted lower third molar extraction. J Oral Maxillofac Surg. 2008; 66: 943-947.

[9] Korbendau JM, Korbendau X. (eds.) Clinical success in impacted third molar extraction. Quintessence Publishing, Paris, 2002.

[10] Winter GB. Principles of exodontia as applied to the impacted mandibular third molar: a complete treatise on the operative technic with clinical diagnoses and radiographic interpretations. American Medical Book Company, St. Louis, MO, 1926.

[11] Pell GJ, Gregory GT. Impacted mandibular third molars (classification and modified technique for removal). Dent Digest. 1933; 39: 330-338
[12] Szalma J, Lempel E. Protecting the inferior alveolar nerve: coronectomy of lower third molars. [A nervus alveolaris inferior védelmében: alsó bölcsességfogak coronectomiája.] Orv Hetil. 2017; 158: 1787-1793. [ Hungarian]

[13] Kaposvári I, Körmöczi K, László ZsB, et al. Prospective randomized study regarding the effect of the preoperative antibiotic and chlorhexidine rinse on wound healing after mandibular third molar surgery. [A preoperatív antibiotikus és antiszeptikus kezelés hatása a mútéti úton eltávolított alsó bölcsességfogak sebgyógyulására - prospektív randomizált vizsgálat.] Orv Hetil. 2017; 158: 13-19. [Hungarian]

[14] Piecuch JF, Arzadon J, Lieblich SE. Prophylactic antibiotics for third molar surgery: a supportive opinion. J Oral Maxillofac Surg. 1995; 53: 53-60.

[15] Goldberg MH, Nemarich AN, Marco WP 2nd. Complications after mandibular third molar surgery: a statistical analysis of 500 consecutive procedures in private practice. J Am Dent Assoc. 1985; 111: 277-279.

[16] Pasqualini D, Cocero N, Castella A, et al. Primary and secondary closure of the surgical wound after removal of impacted mandibular third molars: a comparative study. Int J Oral Maxillofac Surg. $2005 ; 34: 52-57$.

(Kaposvári István dr., Budapest, Mária u. 52., 1085 e-mail: kaposvari.isti@gmail.com)

\section{NOTA \\ Új fejlesztés az egészségügyben dolgozók, tanulók részére!}

\section{A magyar nyelvứ szakirodalmi keresőszolgáltatás}

\section{MI a NOTA?}

Napivizit Orvosi Tudástár Alkalmazás

Mit tud a NOTA portál?

Megkönnyíti a magyar nyelvű szakirodalmi források keresését.

Eszköztöl függetlenül, akár okostelefonról, a betegágy mellett állva is használható.

\section{Miben kereshet a NOTA-val?}

Az Akadémiai Kiadó folyóirataiban: Orvosi Hetilap, Magyar Sebészet, Mentálhigiéné és Pszichoszomatika.

Más kiadók magyar nyelvú szakfolyóirataiban: pl. Lege Artis Medicinae, Hypertonia és Nephrologia, Ideggyógyászati Szemle.

A hatályos szakmai irányelvekben.

Magyar nyelvü kérdésekre adott ango nyelvű találatokban, a PubMeden.

\section{nota.hu}

Amennyiben további információra lenne szüksége, keressen minket elérhetőségeinken:

journals@akademiai.hu /hirdetes@akademiai.hu

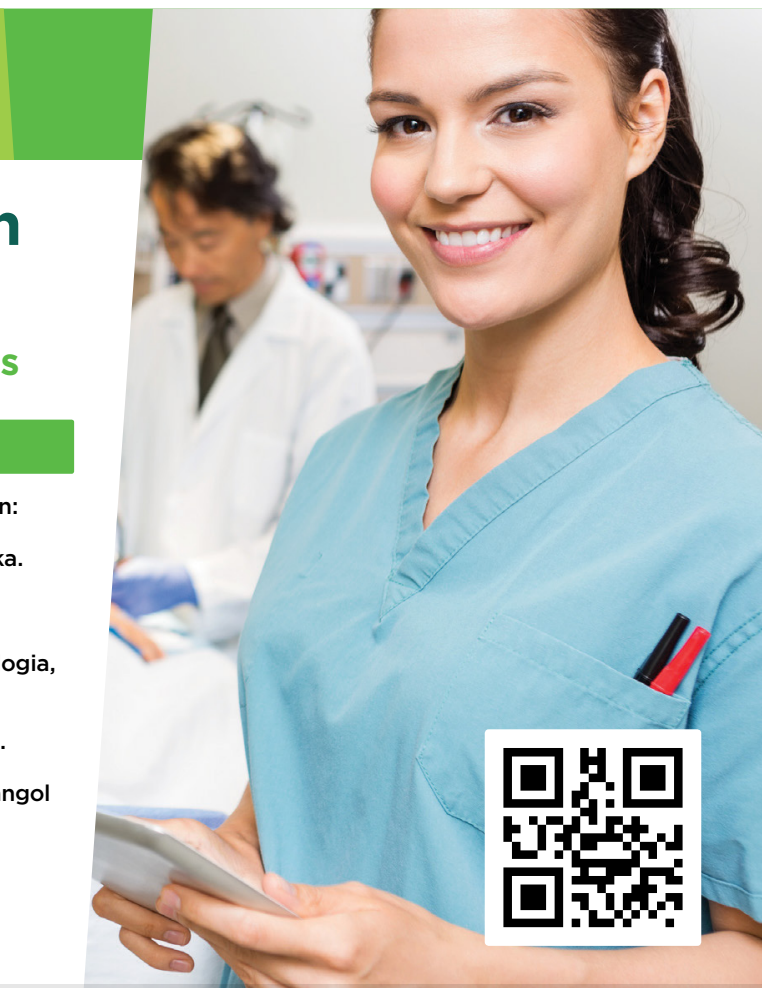

\section{Akadémiai Kiadó}

A Wolters Kluwer Csoport tagja

1117 Budapest, Prielle Kornélia u. 21-35. / Telefon: (1) 464-8246

www.akademiai.hu / www.akademiai.com
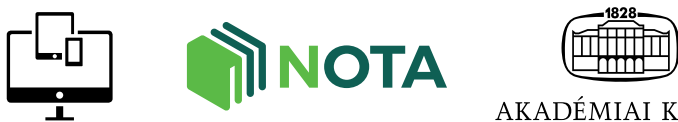

AKADÉMIAI KIADÓ

A cikk a Creative Commons Attribution-NonCommercial 4.0 International License (https://creativecommons.org/licenses/by-nc/4.0) feltételei szerint publikált Open Access közlemény, melynek szellemében a cikk nem kereskedelmi célból bármilyen médiumban szabadon felhasználható, megosztható és úiraközölhető, feltéve, hogy az eredeti szerzỏ és a közlés helye, illetve a CC License linkje és az esetlegesen végrehajtott módositások feltüntetésre kerülnek. 